\title{
A comparative study of ADA and WHO criteria for screening of gestational diabetes mellitus
}

\author{
Jeyamani Baskaran, Subha Sivagami Sengodan*, Anbarasi Pandian
}

Department of Obstetrics and Gynecology, Government Mohankumarmangalam Medical College, Salem, Tamil Nadu, India

Received: 20 December 2017

Revised: 04 January 2018

Accepted: 24 January 2018

*Correspondence:

Dr. Subha Sivagami Sengodan,

E-mail: drppsamysubha@gmail.com

Copyright: () the author(s), publisher and licensee Medip Academy. This is an open-access article distributed under the terms of the Creative Commons Attribution Non-Commercial License, which permits unrestricted non-commercial use, distribution, and reproduction in any medium, provided the original work is properly cited.

\begin{abstract}
Background: Gestational diabetes mellitus is defined as carbohydrate intolerance with its onset or first recognition during present pregnancy. Objective of present study was to compare screening accuracy of ADA and WHO criteria for screening of gestational DM.

Methods: This is a prospective comparative study using ADA and WHO criteria for the screening of GDM. Our objective was to study the implication of implementing the ADA guidelines and WHO guidelines for screening and diagnosis of GDM in 200 antenatal patients at Government Mohankumaramangalam Medical College, Salem during a period of one year from July 2015 to June 2016. All antenatal women attending AN OP between 24-28 weeks of gestation are subjected to fasting blood glucose measurement followed by an oral OGTT using 75 gms of glucose load. Venous blood samples are collected at the end of $1 \mathrm{hr}$ and $2 \mathrm{hr}$. The ADA and WHO criteria were applied separately for each subject to diagnose GDM

Results: As per ADA criteria presence of any one of either, Fasting blood sugar- $92 \mathrm{mg}(5.1 \mathrm{mmol} / \mathrm{L}), 1 \mathrm{hour}$ postprandial-180mg $(10.00 \mathrm{mmol} / \mathrm{L}), 2$ hour postprandial: $153 \mathrm{mg}(8.5 \mathrm{mmol} / \mathrm{L})$ was used for the diagnosis of GDM.As per WHO criteria presence of any one of either, Fasting blood sugar- $126 \mathrm{mg} / \mathrm{dl}(7 \mathrm{mmol} / \mathrm{dl})$ or 2 hour postprandial- $140 \mathrm{mg} / \mathrm{dl}(7.8 \mathrm{mmol} / \mathrm{dl})$ for diagnosis of GDM. The $2 \mathrm{hr}$ value has the statistical significance in the diagnosis of GDM. The $1 \mathrm{hr}$ value done in ADA criteria does not have statistical significance when compared to $2 \mathrm{hr}$ value.

Conclusions: Universal screening for GDM is necessary to diagnose Gestational Diabetes Mellitus. Universal screening may not be feasible in resource poor settings, but it definitely improves the pregnancy outcomes considering the high prevalence of gestational diabetes in India.
\end{abstract}

Keywords: Antenatal women, ADA criteria, Gestational diabetes mellitus, OGTT, WHO criteria

\section{INTRODUCTION}

Gestational diabetes mellitus is defined as carbohydrate intolerance with its onset or first recognition during present pregnancy. ${ }^{1}$ GDM is major health problem in many parts of the world and the prevalence rate vary considerably depending upon the population screened and the type of diagnostic method used. Early detection and achieving normoglycemia during pregnancy can prevent complications not only during pregnancy but also later in life for both mother and baby. ${ }^{2}$

Therefore, the need for universal screening is well recognized especially. Indian women have 11-fold high 
risk of developing GDM compared to Caucasian women. ${ }^{3}$ Many women in developing countries avail antenatal care late in second or third trimester or many approach the health facility during labour without attending any AN clinic. In India every year about 27 million pregnancies occur and all these women need to be screened for GDM.

Considering the wide gap between the target and reality, a practical cost effective, easy and convenient screening test is required so that the women can be tested during their initial visit. No uniform guidelines are followed for screening of GDM so far around the world. Due to the controversy between different associations in GDM screening, IADPSG criteria has been accepted by most associations including ADA., ${ }^{4,5}$

WHO criteria were used as gold standard to assess the sensitivity and specificity of the ADA criteria in the diagnosis of GDM. ${ }^{6}$ Hence the study was conducted to compare the two criteria ADA and WHO for diagnosis of GDM in our population.

\section{METHODS}

This prospective comparative study was conducted in Government Mohankumaramangalam Medical College, a tertiary care hospital at Salem, Tamil Nadu, India. The study population comprised of 200 pregnant women attending antenatal outpatient department with singleton pregnancy between 24-28 weeks.

Antenatal women with gestational age between 24 and 28 weeks were asked to come in fasting state by telephonic call given one day prior to test timing. Fasting blood sample taken. $75 \mathrm{gm}$ of glucose given, and venous sample taken at the end of $1 \mathrm{hr}$ and $2 \mathrm{hr}$. They were sent to laboratory for immediate processing and reporting. The ADA and WHO criteria were applied separately.

\section{Inclusion criteria}

Pregnant women-singleton pregnancy between 24-28 weeks.

\section{Exclusion criteria}

- Multiple pregnancy

- Gestational age $>28$ weeks

- Overt diabetes mellitus.

\section{RESULTS}

In present study out of 200 patients there were 78 persons above the age of 25 years and 81 persons with $\mathrm{BMI}>25$ $\mathrm{Kg} / \mathrm{m}^{2}$.

2 patients had previous history of GDM and 34 patients had family history of DM. BOH was present in 18 persons and thyroid dysfunction in 4 patients.
Table 1: Risk factors and incidence.

\begin{tabular}{|lll|}
\hline Risk factor & No. of patients & Percentage \\
\hline Age $>25$ years & 78 & 35.2 \\
\hline BMI $>25 \mathrm{~kg} / \mathrm{m}^{2}$ & 81 & 39.8 \\
\hline $\begin{array}{l}\text { Previous history of } \\
\text { GDM }\end{array}$ & 2 & 1 \\
\hline Family history of DM & 34 & 17.3 \\
\hline Bad obstetric history & 18 & 9 \\
\hline Thyroid dysfunction & 4 & 2 \\
\hline
\end{tabular}

When the percentage was calculated, $35.2 \%$ were above 25 years, $39.8 \%$ above BMI $25 \mathrm{~kg} / \mathrm{m}^{2}$, previous h/o GDM was seen in only $1 \%$, family history in $17.3 \%, \mathrm{BOH}$ in $9 \%$, thyroid dysfunction in $2 \%$.

Table 2: Diagnosis by ADA criteria.

\begin{tabular}{|ll}
\hline Gestational diabetes & Total number of \\
mellitus as per ada criteria & participants, N (\%) \\
\hline Present & $28(14.2)$ \\
\hline Absent & $172(85.8)$ \\
\hline Total & 200 \\
\hline
\end{tabular}

As per ADA criteria, 28 patients were found to be GDM patients out of 200. The blood sugar values of the remaining 172 patients was found to be normal. This means only $14.2 \%$ patients were diagnosed and labelled as GDM when the ADA criteria of $153 \mathrm{mgs} \%$ was taken as cutoff.

As per WHO criteria,26 patients were found to be GDM patients out of 200. 174 patients were found to be normal. The WHO cutoff of $140 \mathrm{mgs} \%$ also diagnosed and labeled $13 \%$ of the study population as GDM.

Table 3: GDM diagnosis by WHO and ADA criteria in the high risk group (age $>25 \mathrm{yrs}$ ).

\begin{tabular}{|lllll|}
\hline $\begin{array}{l}\text { ADA } \\
\text { criteria }\end{array}$ & $\begin{array}{l}\text { WHO } \\
\text { criteria } \\
\text { (GDM } \\
\text { present) }\end{array}$ & $\begin{array}{l}\text { WHO } \\
\text { criteria } \\
\text { (no } \\
\text { GDM) }\end{array}$ & $\begin{array}{l}\text { Chi } \\
\text { square }\end{array}$ & $\begin{array}{l}\text { P value } \\
\text { valu }\end{array}$ \\
\hline $\begin{array}{l}\text { GDM } \\
\text { present }\end{array}$ & $9(81.8)$ & $4(6.0)$ & 0.000 & 1.000 \\
\hline No GDM & $2(18.2)$ & $63(94.0)$ & 0.000 & 1.000 \\
\hline Total & $11(14.1)$ & $67(85.9)$ & & \\
\hline
\end{tabular}

The P-Value was 1 . There was no significant difference in the diagnosis d GDM in patients above the age of 25 years, while comparing with the ADA and WHO criteria.

Among the study population, 28 patients were diagnosed to have GDM applying ADA criteria whereas 26 patients by WHO criteria. 21 patients were identified by both criteria. The WHO criteria with a lesser cutoff of $140 \mathrm{mgs} \%$ diagnosed $19 \%$ as GDM whereas the ADA criteria with a higher cutoff $(153 \mathrm{mgs} \%)$ diagnosed only $4.1 \%$ as GDM. 


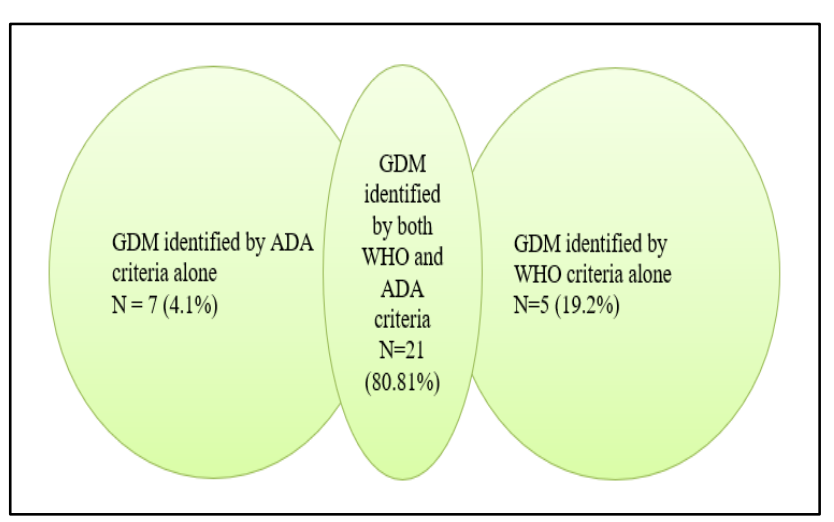

Figure 1: Proportion of GDM patients diagnosed by WHO and ADA criteria.

\section{DISCUSSION}

In the present study mean age was 25 years \pm 2.7 years. The average gestational age at the time of intervention in this study was 26.2 weeks. The mean BMI was significantly increased in GDM as compared to non GDM group $\left(27.54 \pm 4.2 \mathrm{Kg} / \mathrm{m}^{2}\right.$ Vs $\left.24.7 \pm 2.5 \mathrm{Kg} / \mathrm{m}^{2}\right)$. Obesity $\quad\left(\mathrm{BMI} \geq 30 \quad \mathrm{Kg} / \mathrm{m}^{2}\right) \quad$ was significantly more prevalent in GDM women as compared to non GDM ( $2 \%$ Vs $4 \% ; \mathrm{P}<0.01)^{7}$

Previous history of GDM was present in about $1 \%$ of cases. Family history of diabetes was positive in $17.3 \%$ cases. Bad obstetric history was present in $9 \%$ cases and thyroid dysfunction in $2 \%$ of cases. In GDM patients there are various mechanisms like beta cell dysfunction, chronic insulin resistance and autoimmunity which play a role in the causation. Advanced maternal age, obesity, previous $\mathrm{H} / \mathrm{O}$ GDM, family $\mathrm{H} / \mathrm{O} \mathrm{DM}, \mathrm{BOH}$ was significantly higher in GDM patients as compared to nonGDM patients. ${ }^{8}$ The maternal complications which were associated with GDM were preeclampsia, primary caesarean delivery and shoulder dystocia. The increased rate of previous abortion and stillbirth in women with GDM are due to fluctuation in blood sugar level, decreased blood flow through the placenta, placental necrosis, amniotic fluid abnormalities, congenital and metabolic abnormalities, polycythemia. ${ }^{9}$

Risk factor based screening missed about half the cases and pointed out that incidence doubled from $1.45 \%$ to $2.7 \%$ by universal screening in the same population. ACOG recent guidelines 2017 recommended the two step diagnostic approach to screen the women at high risk. 50 gms of oral glucose given and venous blood collected after $1 \mathrm{hr} .140 \mathrm{mg} / \mathrm{dl}$ is taken as cut-off $(7.8 \mathrm{mmol} / \mathrm{L})$. Women exceeding the threshold blood glucose level were given 3 hour oral GTT using 100 gms of glucosefasting, 1 hour and 2 hours. Any one abnormal value is taken as diagnostic of GDM. DIPSI: All pregnant women irrespective of last meal (fasting and non-fasting), $75 \mathrm{gms}$ of oral glucose is given and venous blood collected after $2 \mathrm{hrs}$. Cut off value is $140 \mathrm{mg} / \mathrm{dl}$. It is done at booking,
24-28 weeks and 32-34 weeks. In one step approach on all pregnant women there is an increase in the diagnosis of GDM. From the results of our study the chances of picking up the GDM mothers would be doubled by universal screening. This is more appropriate for the high risk ethnic group like Asians, as suggested by literature. This study has shown that two hour sugar value has maximum sensitivity and specificity in diagnosing GDM and would pick up majority of the cases when performed between 24 and 28 weeks of gestation. Though this cannot replace the gold standard criteria, this can be seriously considered as the investigation of choice in resource poor settings. ${ }^{10}$

As per WHO criteria the cut off at the end of two hours for diagnosing GDM is $140 \mathrm{mg} / \mathrm{dl}$ and that by ADA criteria is $153 \mathrm{mg} / \mathrm{dl}$. When this single value is used for diagnosing GDM in our study, 28 patients would have been labeled as GDM as per WHO criteria as against 23 patients by ADA criteria. So, when a single value of 2 hour blood glucose level is to be decided, it would be desirable to have a cut off as $140 \mathrm{mg} / \mathrm{dl}$. Medical nutrition therapy and exercise forms the backbone of GDM management. ${ }^{8}$ Human insulin is being used for a long time without any adverse effect on the fetus and it do not cross the placenta. Newer short acting Insulin Lispro and Aspart are also now shown to be effective as human insulin without any adverse effects. ${ }^{11}$ Lifelong screening after postpartum period is needed every 3 years. ${ }^{12}$

\section{CONCLUSION}

In this study there is no difference between ADA and WHO in the diagnosis of GDM. Risk factor analysis have no statistical significance and missed about half the cases in the diagnosis of GDM.

In resource poor setting like remote and underdeveloped area it would be cumbersome and expensive to take two blood samples as per WHO criteria and three blood samples as per ADA criteria. This study has shown 2 hour blood sugar value has the maximum sensitivity and specificity in the diagnosis of GDM and cut off 140 $\mathrm{mg} / \mathrm{dl}$ may be taken. It cannot replace the gold standard criteria but it can be considered as one of the investigation in resource poor setting especially when done between 24-28 weeks of gestation.

Hence universal screening for GDM is necessary to diagnose Gestational Diabetes Mellitus. Universal screening may not be feasible in resource poor settings but it definitely improves the pregnancy outcomes considering the high prevalence of gestational diabetes in India.

\section{Funding: No funding sources Conflict of interest: None declared \\ Ethical approval: The study was approved by the Institutional Ethics Committee}




\section{REFERENCES}

1. Expert Committee on the Diagnosis and Classification of Diabetes Mellitus. Report of the expert committee on the diagnosis and classification of diabetes mellitus. Diabetes Care. 2003;26 Suppl 1:S5-20.

2. Dabelea D, Pettitt DJ. Effect of diabetes on pregnancy and offspring: follow up research in the Pima Indians. J Matern Fetal Medicine. 2000;9:83-8.

3. Ben-Haroush A, Yogev Y, Hod M. Epidemiology of gestational diabetes mellitus. Textbook of Diabetes and Pregnancy. 2003:85-6.

4. American Diabetes Association. Gestational diabetes mellitus. Diabetes Care. 2000 Jan;23 Suppl 1:S77-9.

5. Metzger BE, Coustan DR, the Organizing Committee: Summary and recommendations of the Fourth International Workshop-Conference on Gestational Diabetes Mellitus. Diabetes Care. 1998;21(Suppl. 1):B161-B167,

6. WHO Consultation: definition, diagnosis and classification of diabetes mellitus and its complications: report of a WHO consultation. Part 1: Diagnosis and Classification of Diabetes Mellitus. Geneva, WHO/NCD/NCS/99.2, World Health Org., 1999

7. Chu SY, Callaghan WM, Kim SY, Schimid CH, Lau J, England LJ, Et Al. Maternal obesity and risk of gestational diabetes mellitus. Diabetes Care 2007;30:2070-6.

8. American Diabetes Association. Standards of medical care in diabetes-2013. Diabetes Care. 2013;36(Supplement):S11-S66.

9. Hedderson M. Gestational diabetes mellitus and lesser degrees of pregnancy hyperglycemia: association with increased risk of spontaneous preterm birth. Obstet Gynaecol. 2003;102:850-6.

10. Sagili H, Kamalanathan S, Sahoo J, Lakshminarayanan S, Rani R, Jayalakshmi D, Kumar $\mathrm{KH}$. Comparison of different criteria for diagnosis of gestational diabetes mellitus. Indian $\mathrm{J}$ Endocrinol Metabol. 2015 Nov;19(6):824.

11. Bhattacharya A, Brown S, Vice PA. Insulin lispro and regular insulin in pregnancy. QJM Mon J Assoc Physicians. 2001;94:255-60.

12. Tuomilehto J, Lindstrom J, Erikson JG, Valle TT, Hamalainen H, Ilanne-Parikka P et al. Prevention of type 2 diabetes mellitus by changes in lifestyle among subjects with impaired glucose tolerance. $\mathrm{N}$ Engl J Med. 2001;344:1343-50.

Cite this article as: Baskaran J, Sengodan SS,

Pandian A. A comparative study of ADA and WHO criteria for screening of gestational diabetes mellitus. Int J Reprod Contracept Obstet Gynecol 2018;7:95760. 